\title{
Student nurses' learning processes in interaction with psychiatric patients: A qualitative investigation
}

\author{
Linda Kragelund* \\ National Centre of Competence Development, The Danish School of Education, Aarhus University, Tuborgvej 164, 2400 Copenhagen NV, Denmark
}

\section{A R T I C L E I N F O}

\section{Article history:}

Accepted 20 November 2010

\section{Keywords:}

Clinical placement

Learning processes

Obser-view

Psychiatric nursing

Qualitative research

\begin{abstract}
A B S T R A C T
When the Danish government converted the national practice-oriented nursing qualification from a vocational course to a bachelor's degree in 2002, the clinical training component was scaled back. Accordingly, mentors needed to optimise students' learning from this curtailed clinical practice. A fuller understanding of how student nurses function and learn during clinical training is vital. This article presents the findings of a qualitative investigation of student nurses' learning processes during their clinical placement in psychiatric nursing practice. An explorative and qualitative descriptive approach was chosen. The theoretical framework includes Jarvis' concept of 'disjuncture', because it offers a theoretical way of understanding the empirical phenomenon of 'non-routine-situations'. Heller's concept of 'everyday life activities' is also drawn on, for its contribution to understanding and analysing the content of student nurses' learning processes. Data was generated from qualitative, semi-structured interviews with, observations of, and obser-views with, eleven students. The obser-view process is my development. It is a common reflection between researcher and research participant which takes place just after the researcher's observation of the participant in interaction with a patient. The role of the researcher is to be a catalyst for the reflection. Using qualitative content analysis, a model of student nurses learning processes, termed the 'Windmill of Learning Processes' was developed as a result. A key finding is that students and mentors are typically unaware of potential learning situations. Crucially, once students are made aware of this fact, their clinical learning can be enhanced. In this regard, the Windmill of Learning Processes is offered as a pedagogical tool for students and mentors.
\end{abstract}

() 2010 Elsevier Ltd. All rights reserved.

\section{Background}

In Denmark there is only one nursing qualification, and that is a bachelor's degree in general nursing, which takes three and a half years, made up of seven semesters. The course alternates between theoretical and practical training. It contains of 90 ECTS points in clinical practice and 120 ECTS theoretical points (Ministry of Education, 2001).

Clinical placements are always preceded by theoretical modules, taught at a university college, in the related disciplines. So students will be taught theory of psychiatric diseases, psychiatric nursing, psychology and communication before they start their clinical training in psychiatry. Clinical placements in psychiatry last eight weeks each, and take place mainly on psychiatric hospital wards or satellite district psychiatric centres. In Denmark, the terms psychiatry and psychiatric patients are used in place of mental health and mental health service users.

\footnotetext{
* Tel.: +4588889965 .

E-mail address: likr@dpu.dk.
}

The Danish Nursing Education was transformed from vocational training to a bachelor's degree in 2002. The clinical placement component of the course was curtailed, while the objectives of the clinical placement were expanded (Ministry of Education, 2001). This made it vital to establish how the clinical part of the students' training could be optimised. To this end, I conducted a qualitative investigation about student nurses' learning processes in their interaction with patients during their clinical placement in psychiatry (Kragelund, 2006).

The project was conducted in a traditional psychiatric hospital, one of many sited throughout the county. It has 125 beds for patients with a broad spectrum of psychiatric illnesses, and also treats outpatients.

The hospital is organised by wards, each containing between seven and fourteen beds. All patients have their own bedroom, toilet and bathroom. Each ward has a dayroom, a dining room and a kitchen. The hospital staff comprises nurses, nursing assistants, psychiatrists, psychologists, social workers and occupational therapists, numbering approximately 460 in all (Roskilde County Psychiatric Hospital Fjorden). 
Review of the literature

A review of the prevailing nursing education literature published between 2002 and 2004 was undertaken. A variety of keyword combinations, including 'nursing education', 'clinical education', 'clinical learning', 'learning in practice', 'learning processes', 'psychiatric nursing' and 'mental health nursing', were run through relevant databases (Medline, PsycInfo and CINAHL). A number of international nursing journals were also examined, as were individual article references. 300 pertinent articles were found: just under half dealt with student nurses' learning; 28 focused specifically on students' learning during their clinical placement in psychiatry (Kragelund, 2006).

Student nurses' interaction and therapeutic relationships with patients

The literature on student nurses' learning during their clinical placement focuses on how students learn to interact and develop therapeutic relationships with psychiatric patients, and the barriers they face (Lauder et al., 2002; Melrose and Shapiro, 1999; Morrissette, 2004; Munnukka et al., 2002; Rungapadichy et al., 2004; Tully, 2004).

Students are interested in learning how to interact with and relate to patients. To do so, they need mentors as positive rolemodels (Munnukka et al., 2002). However, research shows that mentors sometimes act as poor role-models, which might negatively impact students' learning. Some student nurses observed what they termed 'alleged malpractice', where the nurses did not get involved with the patients, lacked skills, and showed a negative approach to care (Rungapadichy et al., 2004).

Students' opportunities to interact and develop therapeutic relationships with patients can be affected by the learning opportunities on the ward; whether or not students have the chance to talk about their experiences and get feedback (Morrissette, 2004); whether or not students have mentors they can use as positive rolemodels (Munnukka et al., 2002); and finally, students' own ability to interact with and relate to patients (Lauder et al., 2002).

Barriers to learning how to interact with, and relate to, patients, include fear, because students do not know how to care for patients (Melrose and Shapiro, 1999), and stress, because they have to interact with the patients (Morrissette, 2004; Tully, 2004). These barriers can result in them withdrawing from patient interaction (Morrissette, 2004).

\section{Hospital wards as learning environments}

Research shows that for hospitals to serve as effective learning environments, student nurses need support and care from mentors who are interested in mentoring. Such learning environments provide the students with the optimum conditions to obtain the most out of their learning processes. Nevertheless, mentors do not always meet the students' needs, and the time spent in clinical practice is not always used effectively (Chan, 2002; Papp et al., 2003; Pearcey and Elliott, 2004; Saarikoski and Leino-Kilpi, 2002).

What students look for in a learning environment is co-operation amongst staff, and an atmosphere in which they are treated as colleagues. Students appreciate learning situations where they have a possibility to acquire new skills, and to learn the values, attitudes and moral understanding of nurses (Papp et al., 2003; Saarikoski and Leino-Kilpi, 2002). If students observe that mentors do not act as positive role-models, there is an adverse effect on students' learning (Pearcey and Elliott, 2004).

\section{Theoretical framework}

The theoretical framework consists of a synthesis of several pertinent theoretical concepts, including Jarvis' concept of disjuncture, and Heller's concept of everyday life activities. Theoretically, Jarvis' concept of disjuncture has been extended to embrace a concept I have termed collective not-conscious disjuncture. Similarly, I have drawn on Heller's concept of everyday life activities to develop the concept of pseudo-everyday life activities. Both concepts are central to the 'Windmill of Learning Processes' (the 'Windmill model') (Fig. 1) which I developed as a result of my research about student nurses' learning processes during their clinical placement in psychiatry (Kragelund, 2006). The 'Windmill model' is a pedagogical tool which offers a new way of looking at, and talking about, student nurses' learning in clinical practice. Furthermore, it provides a discourse for talking about the learning opportunities that students and mentors are unaware of. The

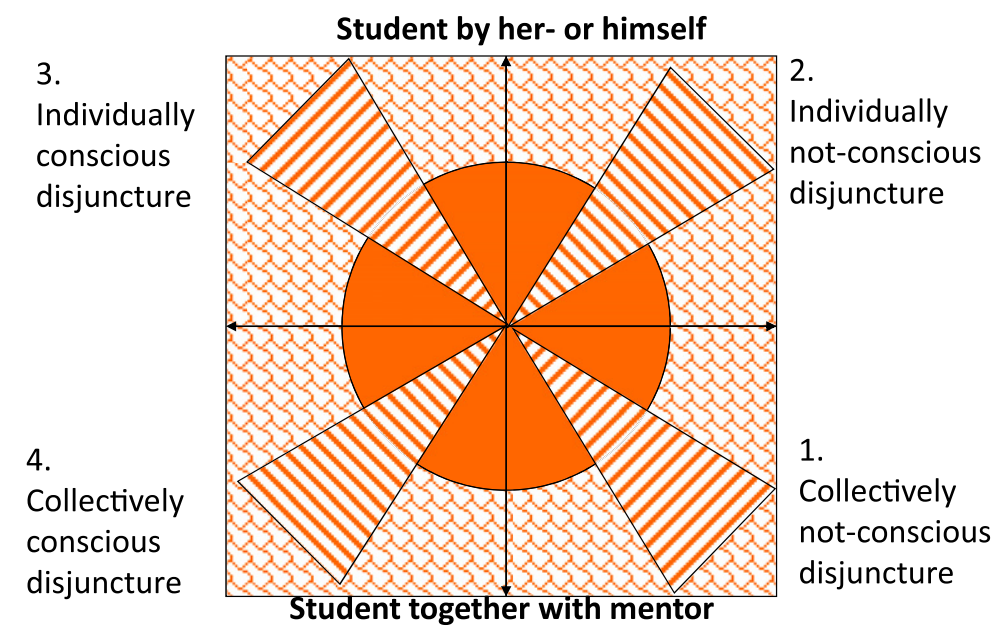

Fig. 1. The Windmill of Learning Processes. 
'Windmill model' is thoroughly described in an article in Nurse Education Today (Kragelund, 2010).

\section{Disjuncture}

Jarvis' concept of disjuncture offers a theoretical way of understanding the empirical phenomenon of 'non-routine situations', which makes it key to the 'Windmill model'. Briefly, Jarvis defines disjuncture as a social situation in which there is a disharmony between a person's previous experiences and the current situation the person finds themselves in (Jarvis, 1987, 2005). Jarvis is of the opinion that it is a fundamental human trait to try to create meaning in social situations. As long as there is harmony between our current situation and our construction of the meaning of that situation, we do not have to question the meaning. It is when we experience the unknown that we ask questions in order to re-establish meaning.

One of Jarvis' basic assumptions is that whenever disharmony occurs, there is potential for learning. This is disjuncture. Such situations are non-routine. According to Jarvis, disjuncture has three aspects:

1. Persons can experience disjuncture either in a current situation, or they can imagine future situations where there will be disjuncture in relation to their knowledge, skills and/or attitudes (Jarvis 1987, 2005). In such situations, disjuncture is obvious to the persons themselves.

2. It is possible to talk about different degrees of disjuncture. They are related to what extent it is routine or non-routine for a person to act in a certain situation. Jarvis argues that as we become accustomed to performing certain actions, we move from acting in an experimental and creative way in novel situations, through to performing repetitively, then routinely, and, finally, ritually and with a sense of alienation.

We perform creative and experimental acts in novel situations. At the other end of the spectrum lie the situations we take for granted. These are situations in which we act pragmatically and automatically. While there is still meaning for the person acting, it is done 'unconsciously'. There is harmony between the person's experiences and their social situation. The situations become routine (Jarvis, 1999).

There is a risk that actions which have become routine lead to ritualism. This is when the performer does not notice the nuances in situations. There is also a risk that persons acting ritually lose their humanity and come to act robotically (Jarvis, 1999).

Ritualism can deteriorate into alienation. This means that acts are performed without meaning for the person who is acting. The work is seen as boring and repetitive. It is worth noting that it may be difficult to judge whether an action is routine or non-routine for any individual. Many situations contain elements of both (Jarvis, 1992a, 1999). One of Jarvis' points is that professionals can also learn in situations with routine actions, because they are able to ask questions both about their actions and the attitudes behind them. They are able to re-generate disjuncture (Jarvis, 1999).

3. It is a question of who is aware or unaware of the disjuncture. Is the person in the situation aware that it is non-routine? If not, are other people in the person's surroundings aware of this (Jarvis, 1987, 1992b, 2005)? Or does neither the person in question nor the surrounding people realise that there is disjuncture?

\section{Pseudo-everyday life activities}

Heller's concept of 'everyday life activities' is useful to understanding and analysing the content of student nurses' learning processes. Everyday life is cyclic, and it consists of 'everyday life activities', which are all those acts people perform daily without reflection or questioning. They are activities that we know will work in specific situations, because they have done so in similar situations. Examples are dressing, eating and shopping (Heller, 1970/1984).

There are many similar acts in psychiatric nursing. These include: making small talk in the sitting room; shopping for meals; meal preparation; eating; going for a walk; playing cards (Kragelund, 2006). Everyday life in psychiatric wards has a cyclic rhythm, and the content is directed by norms-and-rules e.g. house rules, circadian rhythms, and weekly plans.

My research revealed that student nurses were frequently assigned to assist with such everyday life activities. Both student and mentor assumed that these would be routine for the student, when in fact this was contradicted by the evidence. In practice, the students did not know how to act, and would often make mistakes or retreat from the situations altogether. These activities are termed by me as 'pseudo-everyday life activities' because they take place in the context of clinical psychiatry. Such activities are potential learning situations.

\section{Methodology}

\section{Underpinning philosophy and research design}

The underpinning philosophy of my research is consistent with a social constructivist perspective. It means that my ontology is based on the existence of a common material world, but that people can experience it differently. It also means that my epistemological point of view is that knowledge is context-bound and relativistic.

A qualitative descriptive and explorative approach was chosen, because review of the literature shows that research in relation to student nurses' learning processes in interaction with psychiatric patients is sparse (Kragelund, 2006).

The purpose of the study was to describe and explain student nurses' learning processes in non-routine situations (equivalent to the theoretical concept of disjuncture) where they interact with psychiatric patients, in order to understand the characteristics of these learning processes. The ultimate aim is to optimise clinical learning.

\section{Sample}

There are no rules in qualitative research about how many participants are needed, but the numbers sampled have to be weighed against the purpose of the research. A guiding principle is to reach data saturation, which is: ' ... sampling to the point at which no new information is obtained and redundancy is achieved' (Polit and Beck, 2004, p. 308). A volunteer sample of eleven students joined the project, and data saturation was reached.

I canvassed two classes of students during their fourth semester (theory of psychiatry and psychiatric nursing). Eleven students volunteered for the project, to be conducted during their clinical psychiatry placements in the fifth semester. They were all female, with an average age of 31.4. They got their training in eleven different hospital wards. The volunteers' personal and professional backgrounds can be seen in Fig. 2 .

\section{Data generating}

Data was generated from qualitative, semi-structured interviews (interviews) with, observations of, and obser-views with the research participants. 
L. Kragelund / Nurse Education in Practice xxx (2010) 1-8

\begin{tabular}{|c|c|c|c|c|c|c|c|}
\hline Sex & $\begin{array}{l}\text { Average } \\
\text { of age }\end{array}$ & \begin{tabular}{|l|} 
School \\
education
\end{tabular} & $\begin{array}{l}\text { Vocational } \\
\text { education }\end{array}$ & $\begin{array}{l}\text { Marital } \\
\text { status }\end{array}$ & Children & $\begin{array}{l}\text { Relevant } \\
\text { experience }\end{array}$ & Why nursing? \\
\hline $\begin{array}{l}11 \text { women } \\
0 \text { men }\end{array}$ & $\begin{array}{l}31.4 \\
\text { years }\end{array}$ & $\begin{array}{l}4 \text { high school } \\
7 \text { A-levels }\end{array}$ & $\begin{array}{l}1 \text { masseur } \\
1 \text { clerk } \\
1 \text { assistant } \\
\text { accountant } \\
1 \text { state- } \\
\text { registered } \\
\text { chiropodist } \\
1 \text { nursing } \\
\text { assistant } \\
1 \text { public servant } \\
5 \text { no vocational } \\
\text { training }\end{array}$ & $\begin{array}{l}5 \text { married } \\
4 \text { live-in } \\
\text { partner } \\
1 \text { boyfriend } \\
1 \text { no } \\
\text { boyfriend }\end{array}$ & \begin{tabular}{|l}
6 with two \\
children \\
each aged \\
$2-22$ years \\
5 without \\
children
\end{tabular} & $\begin{array}{l}6 \text { nursing } \\
\text { auxiliaries } \\
1 \text { nursing assistant } \\
7 \text { with experiences } \\
\text { of illness in the } \\
\text { family }\end{array}$ & $\begin{array}{l}3 \text { by chance } \\
5 \text { a long-held } \\
\text { desire } \\
3 \text { the interests } \\
\text { developed over } \\
\text { time }\end{array}$ \\
\hline
\end{tabular}

Fig. 2. Participants' backgrounds.

Interviews are the ideal format for unpacking complicated topics and providing an understanding of the respondent's acts, motives and individual perspectives and experiences (Jensen and Johnsen, 2000; Kvale, 2007; Polit and Beck, 2004).

Each student was interviewed three times: before, immediately after, and three months after, their clinical placement. The aim was to generate data about the students' learning processes as seen from their perspective: an inside perspective. My assumption was, that the students would hold a different view on their learning processes with the passage of time.

The role of field researcher falls somewhere between the complete participant and the complete observer, but "...most field research involves roles somewhere between these two poles" (Hammersley and Atkinson, 2005, p. 107). In some situations I served as participant as observer, and in others as observer as participant. My role differed from situation to situation.

My intention was to observe each student three times; at the beginning, in the middle and at the end of their clinical placement, and so gain an outside perspective on data, which in this case meant my perspective on the students' learning processes. However I only observed the eleven students for 28 days in all. Sometimes something unforeseen happened, and the students did not want me to observe them. I expected that through observations I would be able to describe the students' learning possibilities and the context of leaning, and also to uncover learning processes that the students themselves were not aware of.

The obser-view process is a methodology which enables the researcher to develop a deeper understanding of data than is possible from observation alone. In my research, I was able to uncover the students' reflections before, during, and after their interaction with a patient. Seen from the students' perspective the obser-views gave them the chance to round off the day by verbalising and reflecting on the day's experiences.

Obser-view is understood to mean a dialogue between research participant and researcher in which they reflect on experiences they have had during the researcher's observation of the participant. The reflection takes place as a continuation of the researcher's observation. The role of the researcher is that of catalyst for reflection. Understood in this way, the obser-view becomes both a methodology to generate data, and a learning space (Kragelund, 2006, 2007a, in press).

At the outset, the obser-view was not part of the research design. Nevertheless, I found the students wanted to talk to me and reflect on the situations we had both been part of. I realised that it could be useful from a research perspective, since obser-views would provide an inter-subjective perspective on the data. It is not the goal of an obser-view to provide the parties with a common understanding, but to give both a more nuanced perspective of the situation in question.

Combining the three perspectives gained from interview, observation and obser-view increases the internal validity of the research project.

All interviews and obser-views were tape recorded and transcribed. Field notes were made during the observations, and my reflections were logged after the observations. The raw data was transferred to electronic form, and revised into a coherent text. The empirical material comprises over 1000 transcribed pages.

\section{Analytical approach}

The unit of analysis was non-routine situations where students interacted with psychiatric patients. Every unit of analysis consisted of three elements: beginning, interaction between student and patient, and aftermath.

Qualitative content analysis, inspired by Cavanagh was used. There is no one right way to do qualitative content analysis, but as in all kind of research a condition is, that the researchers have identified research questions, theories, assumptions and consciously choose empirical data, they are going to analyse. Qualitative content analysis includes both deduction, induction and abduction (Cavanagh, 1997). The three types of data were analysed together. I used deduction; the analysis took departure in the research questions and the topic guide, I had developed for the qualitative interviews. It gave me no new insight except from what I already knew because of my assumptions (Patton, 1980), but I did categorise and reduce data, which is an important part of qualitative content analysis (Blaikie, 1993; Jensen and Johnsen, 2000). All units of analysis were identified and primarily analysed through induction, and the 'Windmill model' is primarily based on abduction. It can be described as a swing of the pendulum between empirical data and theoretical concepts (Bitsch Olsen and Pedersen, 2003).

Through the qualitative content analysis three main categories emerged, which had to do with the content of the students' learning processes. They were: pseudo-everyday life activities, professional socialisation and development of professionalism. The three main categories showed different types of learning processes, which was a sign of difference in the empirical material. That made it also possible to categorise all units of analysis in relation to if the students on their own (individual) or together with staff (collective) were aware or unaware that they were in a non-routine 
situation. It meant that four more main categories emerged: collective conscious disjuncture, individual conscious disjuncture, individual not-conscious disjuncture and collective not-conscious disjuncture. Altogether the analysis showed 12 main categories. Empirical findings were confronted with existing theories about learning processes, everyday life, professionalism and professional socialisation. A synthesis between theoretical concepts and empirical data resulted in development of the concepts of 'collective not-conscious disjuncture' and 'pseudo-everyday life activities' and in the 'Windmill of Learning Processes'.

Transcriptions of interviews, obser-views and observations were read and re-read in order to undertake the qualitative content analysis.

\section{Ethical issues}

Informed written consent was sought from the student nurses and they were guaranteed confidentiality and anonymity. To maintain confidentiality, pseudonyms have been used for all participants.

Permission was obtained from mentors, patients and the Director of Nursing.

The Danish Data Inspection Institution and the Danish Ethics Committee reviewed and approved the project.

\section{Findings and discussion}

The investigation shows that student nurses' learning processes can be categorised as one of four types of disjuncture: collective conscious disjuncture, individual conscious disjuncture, individual not-conscious disjuncture and collective not-conscious disjuncture.

Jarvis identifies the first three types of disjuncture, but uses different phrasing (Jarvis, 1987, 1992b, 2005). The terminology 'individual' versus 'collective', and 'conscious' versus 'not-conscious', is my own.

In the course of my qualitative content analysis, it emerged that the units of analysis do not fit neatly into Jarvis' three categories. I realised that there is a fourth category, which I call 'collective notconscious disjuncture' (Kragelund, 2006).

The content of potential learning situations falls into three categories based on the following assumption: to become a nurse entails both learning to be a nurse (professional socialisation) and learning to perform nursing (develop professionalism). Learning to be a nurse and learning to perform nursing are two complementary elements of content. The third, overlapping element, is 'pseudoeveryday life activities' (Kragelund, 2006).

Professional socialisation (learning to be a nurse) is defined here as the student's acquisition of the unwritten norms-and-rules and attitudes of the field. Empirical examples from the Danish field of psychiatry are: a nurse is not to talk with patients about the latter's personal problems in public; and when a patient talks about committing suicide, this is to be reported immediately to more qualified members of staff.

Developing professionalism (learning to perform nursing) is defined here as the student's acquisition of the knowledge and skills necessary to perform nursing professionally. Examples from the Danish field of psychiatry are: establishing contact with patients; confronting patients when they have not kept an agreement; setting limits for patients; and containing patients' projections.

Empirical examples of pseudo-everyday life activities from the Danish field of psychiatry are: sitting in the dayroom making small talk with patients; and having lunch with patients.

It can be difficult to differentiate between these three elements. As professional socialisation and development of professionalism can be complementary, in many situations the students have the opportunity both of learning to be a nurse, and of developing professionalism. It can be argued that it is a simplification to define the learning content thus because they reduce reality. On the other hand, they help to simplify complexity and allow us to understand student nurses' learning processes in non-routine situations where they interact with psychiatric patients.

A supporting clinical learning environment is essential for student nurses' learning (Chan, 2002), and clinical practice must ensure students' learning opportunities. Nevertheless, investigations show that many hospital wards do not live up to this ideal, and that the limited time students spend in clinical practice is not used effectively. Chan argues for the need for further investigation in that regard (Chan, 2002). To this end, an Action Research Project is underway in Denmark, using the Windmill model as a pedagogical tool for students and their mentors in psychiatric hospital wards (Kragelund et al., 2008).

Outside of this project, the Windmill model can enable students to fully exploit their learning opportunities, and make their clinical training more effective, something which is rarely achieved, according to studies by Chan (2002), Papp et al. (2003) and Pearcey and Elliott (2004).

Even though some research shows that students prefer ad hoc rather than structured and planned mentoring (Melrose and Shapiro, 1999), the 'Windmill model' can be used prior to a student's interaction with a patient. I would argue that using the 'Windmill model' in advance will help both the students and their mentors to prepare for the learning process by identifying the type of situation the students are entering in terms of disjuncture and the learning content. This preparatory work will optimise the students' clinical learning (Kragelund, 2007b).

\section{Collective conscious disjuncture}

In situations characterised as collective conscious disjuncture, both student and mentor are aware that the student is in a nonroutine (learning) situation (Fig. 1, quadrant 4). An example of collective conscious disjuncture can be seen in a situation where student nurse Ann was taking care of a woman with anorexia nervosa. They had agreed that the patient should write about her thoughts and feelings about being ill. The patient did not keep to the agreement, and Ann decided to confront her about that. Ann related:

'...the worst was, when I had to go into her room and ask her, "How come you did not keep the agreement?" I really felt I did not know how I was going to ask her. How would I ever be able to say those things to her? Then my mentor said "Just do as you usually do". And I thought: What do I usually do? I was back to zero, and thought I would never go to manage' (Ann in Kragelund, 2006).

In this situation both Ann and her mentor were aware that it was a non-routine situation for Ann to confront the patient (Fig. 1, quadrant 4). Their awareness of this learning situation made it possible for them to talk in advance about how Ann could handle it, and it also made it possible for them to discuss how Ann had interacted with the patient in the aftermath.

My data analysis shows that potential learning situations characterised by collective conscious disjuncture typically have to do with development of professionalism (Fig. 1, the 'circle'). In the example above, Ann learned to perform nursing through confronting a patient who had not kept an agreement.

\section{Individual conscious disjuncture}

In situations characterised by individual conscious disjuncture, students are aware that they are in a non-routine situation. It is situations where they typically have the opportunity of attaining 
experiences of all three types of learning content (Fig. 1, quadrant 3 ). An example of individual conscious disjuncture is a situation where student nurse Frida was planning to interact with a patient suffering from schizophrenia. Frida did not know what to do. She said: 'I need to get hold of myself. I do not know what I am going to say to the patient. How am I going to interact with her?' (Frida in Kragelund, 2006). In this situation, Frida had the opportunity to develop professionalism by trying to interact with a patient. If Frida and her mentor had prepared Frida for the interaction by using the 'Windmill model', Frida might have felt more confident about interacting with the patient. Her mentor might have coached her in an appropriate way about how to interact with a patient suffering from schizophrenia, and thus get the most out of this learning experience (Chan, 2002; Papp et al., 2003; Pearcey and Elliott, 2004).

\section{Individual not-conscious disjuncture}

Individual not-conscious disjuncture is characterised by situations in which students alone are not aware that they are in a nonroutine situation (Fig. 1, quadrant 2). It is often situations wherein students interact with patients on their own. Typically, these are situations where students are acting in pseudo-everyday life activities: both they and their mentors take it for granted that the students will be able to handle such situations as routine, but often the situations turn out to be non-routine. My data analysis shows that students often make mistakes, and their acts fail. This was the case in a situation where student nurse Kate was making small talk with a patient in the dayroom, and began discussing the patient's alcohol addiction. It is an unspoken Danish rule in psychiatry that nurses are not to talk with patients about the latter's personal problems in public. Kate did not know that, and talked with the patient in the dayroom about the latter's alcohol addiction. Kate said:

'But then another patient turned up and sat down opposite us. And we continued our talk. Then the patient who had come into the sitting room interrupted and said: "I do not think that you should have this talk here." I got really embarrassed, because I realised immediately that she was right.' (Kate in Kragelund, 2006).

Kate was acting in a pseudo-everyday life activity. She had the opportunity to become professionally socialised in relation to an unwritten norm-and-rule about not talking with patients about their personal problems in public (Fig. 1, quadrant 2). This situation is an example of how an unforeseen event can render a familiar situation non-routine. In general, the student might only identify disjuncture at the point when the patient or someone else does something other than what the student expects during an otherwise routine situation. Consequently Kate did not know how to react to the second patient's comment. Thus individual notconscious disjuncture (Fig. 1, quadrant 2) was transformed to individual conscious disjuncture (Fig. 1, quadrant, 3) (Kragelund, 2006). Using the 'Windmill model' prior to the students' interaction with patients might pre-empt them from not knowing how to take care of the patients, thus reducing their experience of stress in situ, and eliminating their instinctive desire to withdraw from patient interaction (Morrissette, 2004; Tully, 2004). Thus if Kate and her mentor had discussed her task (making small talk with patients in the dayroom) in advance, preferably using the 'Windmill model' as the point of departure for discussion, they might have (dis)covered potentially difficult and new topics that should or should not be aired in this public space. In any event, Kate would have had the advantage of considering possible pitfalls and setbacks, giving her the tools to assess her uncomfortable situation more effectively and less emotionally, so lessening the shock. As it was, Kate came away with what she labelled a negative learning experience, which made her insecure throughout the remainder of her clinical training.

\section{Collective not-conscious disjuncture}

Collective not-conscious disjuncture characterises situations in which neither the student nor the mentor is aware that the student is in a non-routine situation (Fig. 1, quadrant 1). Eating lunch or going for a walk with patients, or administering medicine to them are routine for mentors. Collective not-conscious disjuncture often occurs in situations where mentors no longer ask questions about their own way of behaving in relation to the patients, or in relation to their attitudes behind their actions. Often, these situations have to do with professional socialisation. This is exemplified in an example where student nurse Julie was having lunch with a patient. Another unspoken rule in Danish psychiatric practice is that when a patient mentions suicide, this should be reported immediately to more qualified members of staff. Julie was having lunch with a patient in her bedroom, when the latter talked about committing suicide. However, Julie did not report this to the nurse until $2 \mathrm{~h}$ later. Julie said:

'I had the impression that I could leave her unsupervised without any cause for concern, and I left the room a couple of times. Finally, I told the nurse what had happened. She became angry, because I had not told her immediately what the patient had said about committing suicide.... She said that if she had known, she would not have lent the patient a pair of scissors. I will remember it, because it is important' (Julie in Kragelund, 2006).

Now, it is routine for a nurse to have lunch with patients, but neither the mentor nor Julie was aware that it was a non-routine situation for a student nurse to do the same. At the beginning of the encounter, the situation was characterised as collective notconscious disjuncture (Fig. 1, quadrant 1), and in the aftermath, by collective conscious disjuncture (Fig. 1, quadrant 4). Julie was acting in a pseudo-everyday life activity. This gave her the opportunity both of being professionally socialised (learning about the unwritten norm-and-rule that when a patient talks about committing suicide, this should immediately be reported to more highly-trained staff), and of learning to perform nursing (interacting with a patient, and containing a patient's projections). In the aftermath of her interaction with the patient, Julie and her mentor became aware that Julie had been in a nonroutine situation. Individual not-conscious disjuncture (Fig. 1, quadrant 2) was transformed to collective conscious disjuncture (Fig. 1, quadrant 4).

The 'Windmill model' can be usefully exploited after a student's interaction with a patient in order for student and mentor to identify the type of disjuncture the student experienced, and the type of learning that took place. In addition, they can discuss whether or not the learning and teaching strategies they used were appropriate. They will be able to identify whether the student's learning process was transformed from one type of disjuncture to another during the interaction, or in the discussion afterwards. They can plan how they should handle a similar situation in the future in order to fully exploit the student's learning potential. This discussion can be seen as a space for students to talk about their experiences and receive useful feedback (Morrissette, 2004). Unfortunately none of this took place in Julie's case.

Earlier research findings indicate that students place a great deal of importance on their relationship with their mentors (Chan, 2002; Papp et al., 2003; Saarikoski and Leino-Kilpi, 2002), and as Pearcey and Elliott found from their research, watching nurses perform their jobs strongly influences students' choice of a nursing 
career. Findings showed that students felt that they learned more from negative than positive role-models (Pearcey and Elliott, 2004). Bearing this in mind, it would seem a good idea for mentors to work together with their students in order to uncover situations characterised by collective not-conscious disjuncture, in order to create the opportunity for students to learn, and for mentors to further develop their own nursing skills.

Jarvis states that professionals are able to re-generate disjuncture within routine situations, because they know to ask questions about their own actions, and about their attitudes behind those actions (Jarvis, 1999). Mentors, in the research presented in this article, did not always 'remember' to re-generate disjuncture. However, using the 'Windmill model' as a pedagogical tool might be useful in this respect. The overall aim should be to develop nursing practice, optimise student nurses' clinical learning, and make a nursing career more desirable to students once they see how it is possible to develop their nursing practice, as well as an innovative learning environment for both themselves and staff.

\section{Limitations}

The external validity of the current study is limited by the small sample size $(n=11)$. Yet, despite the low sampling, a substantial amount of rich data was generated, data saturation was achieved, and distinct categories emerged during the qualitative content analysis.

The review of the literature spans primo 2002 to ultimo 2004. The article can be criticised for not including more recent research.

The 'Windmill model' was developed in the field of psychiatry in Denmark. I believe that it could also be applicable to other fields of nursing education, and in countries other than Denmark, but more research is required to verify this.

\section{Concluding reflections and recommendations}

This article has explored student nurses' learning processes, and how these processes can be understood. The findings reveal that students' learning processes can be categorised by four types of disjuncture, and by three types of learning content. These concepts are illustrated by the 'Windmill model' (Fig. 1).

The findings allow conclusions to be drawn which have implications for education, nursing practice and research:

Education: using the 'Windmill model' makes it possible to utilise potential learning situations and identify situations with not-conscious disjuncture, thereby optimising students' clinical learning, particularly where students interact with patients in pseudo-everyday life activities.

Development of nursing practice: the 'Windmill model' can be used as a pedagogical tool for uncovering collective not-conscious disjuncture, and re-generating disjuncture in situations where actions and attitudes have become routine for mentors. Consequently, staff and students will experience an innovative learning environment, and patients better nursing care.

Further research: the concepts of collective not-conscious disjuncture and pseudo-everyday life activities can be developed further. To this end, practitioner researchers are conducting an action research project in Danish psychiatric hospitals. By having students and mentors employ the 'Windmill model', the researchers are examining how it works in practice (Kragelund et al., 2008).

Given these findings, it is strongly recommended that students and mentors collaborate in identifying not-conscious learning opportunities, and making them conscious, in order to exploit students' clinical learning, and to further develop nursing practice.
This corresponds with other researchers' recommendations for the development of hospital wards as learning environments for students: where students get the most out of their learning processes, and use their time in clinical practice effectively (Chan, 2002; Papp et al., 2003; Pearcey and Elliott, 2004).

\section{Acknowledgements}

I would like to thank Claudia Gian Rossi for her editing assistance throughout the writing process, and Professor Venka Simovska for her constructive feedback on earlier versions of this article.

Although I have had some assistance in writing this article, any errors and omissions that may remain are mine alone.

\section{References}

Bitsch Olsen, P., Pedersen, K., 2003. Problemorienteret projektarbejde - en værktøjsbog. Roskilde Universitetsforlag, Frederiksberg.

Blaikie, N., 1993. Approaches to Social Enquiry. Polity Press, Cambridge.

Cavanagh, S., 1997. Content analysis: concepts, methods and applications. Nurse Researcher 4 (3), 5-16.

Chan, D.S.K., 2002. Associations between students' learning outcomes from their clinical placement and their perceptions of the social climate of the clinical learning environment. International Journal of Nursing Studies 39, 517-524.

Hammersley, M., Atkinson, P., 2005. Ethnography. Principles in Practice, second ed. 1995 and reprinted 2005. Routledge, London and New York.

Heller, A., 1970/1984. Everyday Life. Routledge and Kegan Paul, London and New York.

Jarvis, P., 1987. Adult Learning in the Social Context. Croom Helm Ltd., London, New York and Sydney.

Jarvis, P., 1992a. Paradoxes of Learning, on Becoming an Individual in Society. Jossey-Bass Publishers, San Francisco.

Jarvis, P., 1992b. Reflective practice and nursing. Nurse Education Today 12 (3), 174-181.

Jarvis, P., 1999. The Practitioner-Researcher - Developing Theory from Practice. Jossey-Bass Publishers, San Francisco.

Jarvis, P., 2005. Towards a philosophy of human learning. In: Jarvis, P., Parker, S. (Eds.), Human Learning. A Holistic Approach. Routledge and Kegan Paul, London and New York.

Jensen, T.K., Johnsen, T.J., 2000. Sundhedsfremme i teori og praksis - En lære-, debat- og brugsbog på grundlag af teori og praksisbeskrivelser. Forlaget Philosophia, Aarhus.

Kragelund, L., 2006. Uddannelse til professionsbachelor i sygepleje - En kvalitativ undersøgelse af sygeplejestuderendes læreprocesser under klinisk uddannelse i psykiatri. Danmarks Pædagogiske Universitets Forlag, København.

Kragelund, L., 2007a. Obser-viewet en metode til at generere data i kvalitativ forskning. Nationalt Center for Kompetenceudvikling, DPU, Aarhus Universitet, København.

Kragelund, L., 2007b. Kategoriseringsmodel for sygeplejestuderendes læreprocesser - et arbejdsredskab til sygeplejestuderende og deres kliniske vejledere. Danmarks Pædagogiske Universitets Forlag, København.

Kragelund, L., 2010. The Windmill of Learning Processes: a learning and teaching tool for student nurses. Nurse Education Today. doi:10.1016/j.nedt.2010.03.015 Elsevier Ltd.

Kragelund, L. Obser-viewet en overset metodik til generering af data i kvalitativ forskning og et lærerum. In: Glasdam, S. (Ed.), Professionsbasseret bacheloropgaveskrivning. Nyt Nordisk Forlag Arnold Busck, København, in press.

Kragelund, L., et al., 2008. Projektbeskrivelse for aktionsforskningsprojektet 'Udvikling af læringsmiljø i psykiatrien: læremuligheder, kompetenceudviklng and Innovation'. Nationalt Center for Kompetenceudvikling, DPU, Aarhus Universitet, København.

Kvale, S., 2007. InterView - En introduktion til det kvalitative forskningsinterview. Hans Reitzels Forlag, København.

Lauder, W., et al., 2002. A comparison of therapeutic commitment, role support, role competency and empathy in three cohorts of nursing students. Journal of Psychiatric and Mental Health Nursing 9, 483-491.

Melrose, S., Shapiro, B., 1999. Students' perceptions of their psychiatric mental health clinical nursing experience: a personal construct theory exploration. Journal of Advanced Nursing 30, 1451-1458.

Ministry of Education, 2001. Departmental Order of Nursing Education, No. 232, 30.03.01. Ministry of Education, Copenhagen.

Morrissette, P.J., 2004. Promoting psychiatric student nurse well-being. Journal of Psychiatric and Mental Health Nursing 11, 534-540.

Munnukka, T., et al., 2002. Integration of theory and practice in learning mental health nursing. Journal of Psychiatric and Mental Health Nursing 9 (1), 5-14.

Papp, I., et al., 2003. Clinical environment as a learning environment: student nurses' perceptions concerning clinical experience. Nurse Education Today 23 (4), 262-268. 
Patton, M.Q., 1980. Qualitative Evaluation Methods. SAGE Publications, Beverly Hills, London.

Pearcey, P.A., Elliott, B.E., 2004. Student impressions of clinical nursing. Nurse Education Today 24, 382-387.

Polit, D.F., Beck, C.T., 2004. Nursing Research: Principles and Methods, seventh ed. Lippinott Williams and Wilkins, Philadelphia.

Roskilde County Psychiatric Hospital Fjorden. Patientinformation. Roskilde County Psychiatric Hospital, Roskilde.
Rungapadichy, D.M., et al., 2004. Mental health nurses' perception of the role of the mental health nurse. Journal of Psychiatric and Mental Health Nursing 11, 714-724.

Saarikoski, M., Leino-Kilpi, H., 2002. The clinical learning environment and supervision by staff nurses: developing the instrument. International Journal of Nursing Studies 39, 259-267.

Tully, A., 2004. Stress, sources of stress and ways of coping among psychiatric nursing students. Journal of Psychiatric and Mental Health Nursing 11 (1), 43-47. 